\title{
EVALUATION OF INTERBODY FUSION TWO YEARS AFTER LLIF PROCEDURE
}

\author{
AVALIAÇÃO DA FUSÃO INTERSOMÁTICA DOIS ANOS DEPOIS DE PROCEDIMENTO DE LLIF \\ EVALUACIÓN DE LA FUSIÓN INTERSOMÁTICA DOS AÑOS DESPUÉS DEL PROCEDIMIENTO DE LLIF \\ Fábio Rosa, ${ }^{1}$ Gabriel pokorny, ${ }^{1}$ Raquel Rodrigues, ${ }^{1}$ Rodrigo Amaral, ${ }^{1}$ Rubens Jensen, ${ }^{1}$ Luiz Pimenta ${ }^{1}$ \\ 1. Instituto de Patologia da Coluna (IPC), São Paulo, SP, Brazil.
}

\begin{abstract}
Objectives: The LLIF technique, extreme lateral interbody fusion, reaches the disc laterally through the psoas muscle, offering adequate access to the disc space with the added benefit of preventing iatrogenic injury to abdominal vascular structures (aorta and vena cava), the sympathetic plexus (reduces incidence of retrograde ejaculation) and neural structures, that is, preservation of the spinal nerves that cross the posterior aspect of the muscle. The objective of this study is to verify the rates of interbody fusion with the LLIF technique. Methods: Retrospective, single center, comparative, non-randomized study. The presence of bone mass with increased hypotransparency in the areas of fusion will be analyzed. For the evaluation of the fusion, the Classification of interbody fusion success: Brantigan, Steffee, Fraser (BSF) will be used. Results: Fifty-nine (86\%) patients presented complete fusion of the approached level (BSF-3) six months after the procedure. One year after the procedure, $87 \%$ of the patients had complete fusion. Similar results were confirmed at two years. Conclusions: We conclude that the technique of lateral interbody arthrodesis is safe and effective for the treatment of low back pain, with a fusion rate of $90 \%$ in two years. Level of Evidence III. Retrospective study, single center, non-randomized.
\end{abstract}

Keywords: LLIF; Arthrodesis; Spinal Fusion.

\section{RESUMO}

Objetivo: A técnica LLIF, fusão intersomática extremo lateral, alcança o disco lateralmente através do músculo psoas, oferecendo acesso adequado ao espaço discal, com benefício adicional de presenvação de lesão iatrogênica de estruturas vasculares abdominais (aorta e veia cava), do plexo simpático (reduz a incidência de ejaculação retrógrada) e de estruturas neurais, ou seja, preservação dos nervos espinhais que cruzam o aspecto posterior do músculo. O objetivo do trabalho é verificar os índices da fusão intersomática com a técnica de LLIF. Métodos: Estudo retrospectivo, em centro único, comparativo e não randomizado. Será analisada a presença de massa óssea, com aumento da hipotransparência nas áreas de fusão. Para a avaliação de fusão, será utilizada a Classification of interbody fusion success: Brantigan, Steffee, Fraser (BSF). Resultados: Cinquenta e nove (86\%) pacientes apresentaram fusão completa do nível abordado (BSF-3) seis meses após o procedimento. Depois de um ano do procedimento, $87 \%$ dos pacientes apresentaram fusão completa. Resultados similares foram constatados em dois anos. Conclusões: Concluímos que a técnica de artrodese intersomática por via lateral é segura e eficaz para o tratamento da dor lombar baixa, com taxa de fusão de $90 \%$ em dois anos. Nível de Evidência III. Estudo Retrospectivo, centro único, não randomizado.

Descritores: LLIF; Artrodese; Fusão Vertebral.

\section{RESUMEN}

Objetivo: La técnica LLIF, fusión intersomática extremo-lateral, alcanza el disco lateralmente a través del músculo psoas, ofreciendo acceso adecuado al espacio discal con el beneficio adicional de preservación de la lesión iatrogénica de estructuras vasculares abdominales (aorta y vena cava), del plexo simpático (reduce incidencia de eyaculación retrógrada) y estructuras neurales, o sea, preservación de los nervios espinales que cruzan el aspecto posterior del músculo. El objetivo del trabajo es verificar los índices de fusión intersomática con la técnica de LLIF. Métodos: Estudio retrospectivo, en centro único, comparativo y no aleatorizado. Será analizada la presencia de masa ósea, con aumento de hipotransparencia en las áreas de fusión. Para la evaluación de fusión, se utilizará la Classification of Interbody Fusion Success: Brantigan, Steffee, Fraser (BSF). Resultados: Cincuenta y nueve (86\%) pacientes presentaron fusión completa del nivel abordado (BSF-3) seis meses después del procedimiento. Un año después del procedimiento, $87 \%$ de los pacientes presentaron fusión completa. Resultados similares fueron constatados en dos años. Conclusiones: Concluimos que la técnica de artrodesis intersomática por vía lateral es segura y eficaz para el tratamiento del dolor lumbar bajo, con una tasa de fusión del 90\% en 2 años. Nivel de Evidencia III. Retrospective study, single center, non-randomized.

Descriptores: LLIF; Artrodesis; Fusión Vertebral.

\section{INTRODUCTION}

The world population has been undergoing an aging process as life expectancy increases. In view of this, an increase in degenerative diseases, among which we highlight those related to the spine, is also expected. ${ }^{1}$ Such spinal disorders are associated with significantly reduced mobility and pain of a mechanical nature that cause an important drop in the quality of life with unquestionable impact at the global level. ${ }^{2}$ There are numerous therapeutic ways to approach low back pain. In most cases, conservative strategies such as physical therapy and muscle strengthening can be used, 
however, a relevant number of these patients do not respond to such treatments, making a surgical approach necessary to relieve pain and restore mobility. ${ }^{3}$ The importance of lumbar fusion is due to the fact that it effectively addresses low back pain resulting from instability, significantly improving patient symptoms and quality of life. ${ }^{4}$ There are several techniques for the approach and fusion of the lumbar spine, with different indications and preferences for each surgeon. ${ }^{4}$ Studies have demonstrated the benefits of anterior approach lumbar surgery, including better access to the anterior spine, ease of implantation of the interbody devices, less blood loss, and a shorter hospital stay when compared to posterior approach fusion. ${ }^{4}$ The XLIF technique, extreme lateral interbody fusion, accesses the disc laterally through the psoas muscle. This approach offers adequate access to the disc space with the additional benefit of preventing iatrogenic injury to the abdominal vascular structures (aorta and vena cava), the sympathetic plexus (reduces the incidence of retrograde ejaculation) and neural structures (that is, of the spinal nerves that cross the posterior aspect of the psoas muscle). ${ }^{5}$ These patients typically suffer from discogenic pain due to segmental instability, disc degeneration, degenerative scoliosis and or grade I or II spondylolisthesis. ${ }^{6-10}$ Thus, the objective of this study is to verify that the use of extreme lateral interbody fusion is safe and effective and offers the same rate of consolidation with less bleeding and a shorter hospitalization.

\section{METHODS}

This was a retrospective, single center, comparative, non-randomized study. The study population consisted of 576 patients who had undergone lateral interbody arthrodesis, meeting the inclusion and exclusion criteria for a period of one or two years.

The inclusion and exclusion criteria were as follows. Inclusion: Patients who underwent XLIF at the IPC, had a CT scan taken at their one- and two-year follow-ups. Exclusion: CT scan of poor quality that did not allow clear observation of the fusion. Patients without a one- or two-year follow-up CT. All patients included in the study filled out the ICF.

The following data were collected: clinical and radiological patient data. Preoperative, intraoperative and postoperative data were collected. In addition, the following radiological data were analyzed: presence of bone mass with an increase in hypotransparency in the areas of the fusion. The fusion was evaluated using the Classification of interbody fusion success: Brantigan, Steffee, Fraser (BSF), ${ }^{11}$ as follows: BSF 1 - radiographic pseudoarthrosis, construction collapse, loss of disc space height; BSF 2 - pseudoarthrosis in progress, area of radiolucency within the bone fusion zone of the cage; and BSF 3 - radiographic fusion, bone bridges in at least half of the fusion area.

The study was approved by the Hospital Moriah Institutional Review Board as registration number 02498818.5.0000.8054.

\section{RESULTS}

Ninety-seven patients with a mean age of 61 years, 40 of whom were male, were included in the study. Thirty-nine patients were excluded for not having the imaging examinations necessary for the evaluation.

Of the 59 remaining patients, $86 \%$ presented total fusion of the operated level (BSF-3) six months after the procedure. One year after the procedure, $87 \%$ of the patients presented total fusion (BSF-3) of the operated level and the same rate of fusion was observed two years after the procedure. (Figure 1)

There was no difference between the male and female sexes in relation to the fusion rate, (Figure 2) nor was there any difference between the different cage sizes in terms of fusion rate. (Figure 3)

There was no significant difference between the clinical outcomes of the BSF1/BSF2 and BSF3 patients. The mean questionnaire scores were: ODI (44.22 \pm 15.77 vs. $26.28 \pm 3,223$; $p>0.05)$; VAS back (6.0 \pm 1.3 vs. $3.5 \pm 0.5 ; p>0.05)$; and VAS legs $(4.0 \pm 2.5$ vs. $2.9 \pm 0.4)$. (Figure 4 )

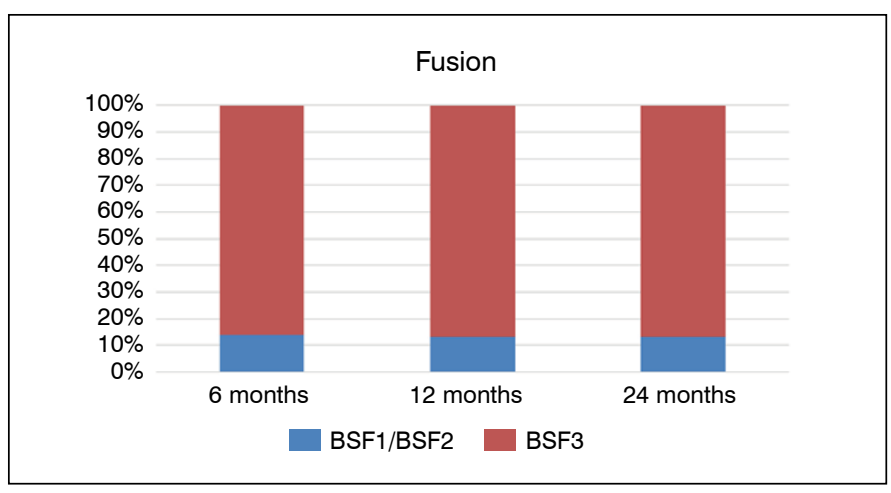

Figure 1. Fusion rate proportions in the following periods: 6 months, 12 months, 24 months. BSF (Brantigan, Steffee, Fraser) Criteria.

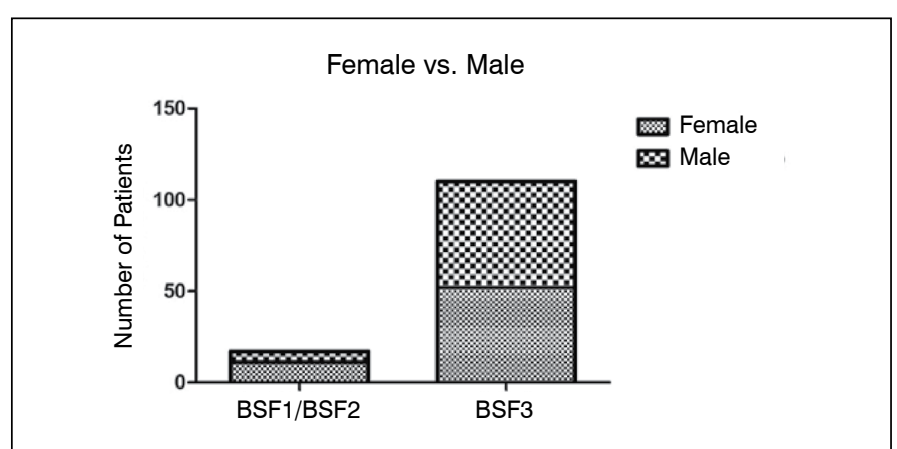

Figure 2. Comparison of the fusion rate after one year between female and male patients. BSF (Brantigan, Steffee, Fraser) Criteria.

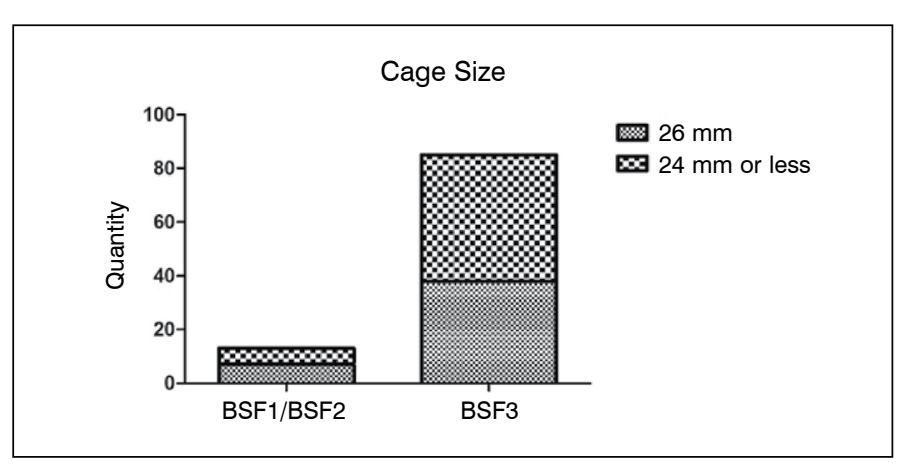

Figure 3. Comparison of the fusion rate between the different interbody device (cage) sizes. BSF (Brantigan, Steffee, Fraser) Criteria.

\section{DISCUSSION}

Lumbar arthrodesis using an interbody device is a topic of great impact when it comes to degenerative spine disease. In this regard, we highlight lateral arthrodesis as it is a minimally invasive approach with less morbidity than the traditional approach. ${ }^{12,13}$ Lateral decubitus reduces morbidity as compared to the prone position. ${ }^{14}$ The risk of nerve root or dural injury is less, the risk of infection is $0.5 \%$ less, and larger implants with a greater fusion area are able to be used. ${ }^{15}$ Both the implant geometry and size contribute to primary stabilization. In general, a greater area of support for the implant reduces the risk of it penetrating the vertebral endplate and of subsidence. ${ }^{16}$ Our data indicated lower complication and surgical revision rates $(6 \%)$ with the lateral implant and a fusion rate higher than $80 \%,{ }^{15}$ with good clinical outcome. The lateral-approach interbody arthrodesis technique is safe and effective for lumbar fusion and indicated for numerous degenerative spine diseases. ${ }^{17-20}$

Patients who underwent lateral interbody arthrodesis, a sample size of 576, with or without posterior supplementation, had their $\mathrm{X}$-ray and tomography examinations analyzed for the rate of fusion 


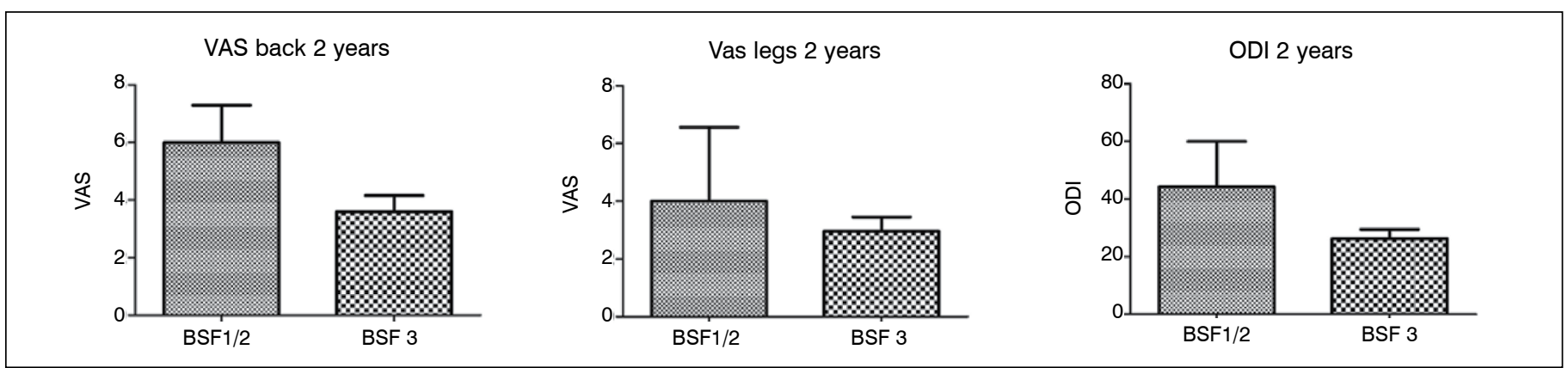

Figure 4. Comparison of clinical outcomes and the interbody fusion rates. BSF (Brantigan, Steffee, Fraser) Criteria.

during a period of 12 months, the minimum follow-up, to 24 months, the maximum follow-up. Images that did not permit ideal verification of the fusion were excluded. We observed complete bone growth (fusion) with bone mass, increased hypotransparency in the fusion areas, and observed bone trabeculation to indicate total fusion. Areas of radiolucency inside the bone fusion area of the cage and the collapse of the construction with the loss of disc space height were also observed.

Even in patients classified as BSF-1, no relevant clinical outcomes were observed in the analysis of the data obtained. ${ }^{21,22}$ These clinical outcomes were not statistically relevant between the BSF-1 and BSF-3 groups. Two factors can explain this outcome. Firstly, the predominance of anterior subsidence together with the high fusion rate had little impact on the decompression of the nerve structures. Secondly, $70 \%$ of the BSF-1 cases were considered low-grade according to Marchi et al. ${ }^{22}$
The limitation of this study is its being both retrospective and single center. The measurement of the fusion rate in X-ray and tomography can have intra- and interobserver variations. A longer follow-up is necessary to predict the frequency of the appearance of adjacent level disease more accurately.

\section{CONCLUSION}

We concluded that the lateral interbody arthrodesis technique is safe and effective for the treatment of low back pain with a fusion rate of $90 \%$ in two years. Only one BSF-1/BSF-2 level became BSF-3 after six months $(1 / 13)$

All authors declare no potential conflict of interest related to this article.

CONTRIBUTION OF THE AUTHORS: Each author made significant individual contributions to this manuscript. FR, RR and GP were the main contributors to the preparation of the manuscript. LP, RJ, RA and FR performed the surgeries, followed-up with patients and gathered the clinic data. FR and GP evaluated the statistical analysis data, conducted the bibliographical research and reviewed the manuscript. LP, RJ, RA and GP contributed to the intellectual concept of the study.

\section{REFERENCES}

1. Waldrop R, Cheng J, Devin C, McGirt M, Fehlings M, Berven S. The Burden of Spinal Disorders in the Elderly. Neurosurgery. outubro de 2015;77 Suppl 4:S46-50.

2. Buser Z, Ortega B, D'Oro A, Pannell W, Cohen JR, Wang J, et al. Spine Degenerative Conditions and Their Treatments: National Trends in the United States of America. Glob Spine J. fevereiro de 2018;8(1):57.

3. Narain AS, Hijji FY, Markowitz JS, Kudaravalli KT, Yom KH, Singh K. Minimally invasive techniques for lumbar decompressions and fusions. Curr Rev Musculoskelet Med. dezembro de 2017;10(4):559-66.

4. Oureshi S, Goz V, McAnany S, Cho SK, Hecht AC, Delamarter RB, et al. Health state utility of patients with single-level cervical degenerative disc disease: comparison of anterior cervical discectomy and fusion with cervical disc arthroplasty. J Neurosurg Spine. maio de 2014:20(5):475-9.

5. Burns BH. An Operation for Spondylolisthesis. The Lancet. junho de 1933;221(5728):1233

6. Fessler R, Khoo L. Minimally Invasive Cervical Microendoscopic Foraminotomy: An Initial Clinical Experience. Neurosurgery. 2002;51(5):S2-45.

7. Hovorka I, de Peretti F, Damon F, Arcamone H, Argenson C. Five years' experience of the retroperitoneal lumbar and thoracolumbar surgery. Eur Spine J Off Publ Eur Spine Soc Eur Spinal Deform Soc Eur Sect Cerv Spine Res Soc. fevereiro de 2000:9 Suppl 1:S30-34.

8. Iwahara T, Ikeda K, Hirabayashi K. Results of Anterior Spine Fusion By Extraperitoneal Approach for Spondylolysis and Spondylolisthesis. Nihon Seikeigeka Gakkai Zasshi. março de 1963:36:1049-67

9. Madan SS, Boeree NR. Comparison of instrumented anterior interbody fusion with instrumented circumferential lumbar fusion. Eur Spine J Off Publ Eur Spine Soc Eur Spinal Deform Soc Eur Sect Cerv Spine Res Soc. 2003;12(6):567-75.

10. McAfee PC Regan JR, Zdeblick T, Zuckerman J, Picetti GD, Heim S, et al. The incidence of complications in endoscopic anterior thoracolumbar spinal reconstructive surgery. A prospective multicenter study comprising the first 100 consecutive cases. Spine. 1995;20(14):1624-32

11. Fogel GR, Toohey JS, Neidre A, Brantigan JW. Fusion assessment of posterior lumbar interbody fusion using radiolucent cages: X-ray films and helical computed tomography scans compared with surgical exploration of fusion. Spine J Off J North Am Spine Soc. 2008:8(4):570-7

12. Rodgers WB, Gerber EJ, Patterson J. Intraoperative and early postoperative complications in extreme lateral interbody fusion: an analysis of 600 cases. Spine. 2011;36(1):26-32
13. Shriver MF, Zeer V, Alentado VJ, Mroz TE, Benzel EC, Steinmetz MP. Lumbar spine surgery positioning complications: a systematic review. Neurosurg Focus. 2015;39(4):E16.

14. Galimberti F, Lubelski D, Healy AT, Wang T, Abdullah KG, Nowacki AS, et al. A Systematic Review of Lumbar Fusion Rates With and Without the Use of rhBMP-2. Spine. 2015;40(14):1132-9.

15. Nemani VM, Aichmair A, Taher F, Lebl DR, Hughes AP, Sama AA, et al. Rate of revision surgery after stand-alone lateral lumbar interbody fusion for lumbar spinal stenosis. Spine. 2014;39(5):E326-31

16. Choi JY. Sung KH. Subsidence after anterior lumbar interbody fusion using paired standalone rectangular cages. Eur Spine J Off Publ Eur Spine Soc Eur Spinal Deform Soc Eur Sect Cerv Spine Res Soc. 2006;15(1):16-22

17. Marchi L, Abdala N, Oliveira L, Amaral R, Coutinho E, Pimenta L. Stand-alone lateral interbody fusion for the treatment of low-grade degenerative spondylolisthesis. ScientificWorld Journal. 2012;2012:456346.

18. Marchi L, Oliveira L, Amaral R, Castro C, Coutinho T, Coutinho E, et al. Lateral interbody fusion for treatment of discogenic low back pain: minimally invasive surgical techniques. Adv Orthop. 2012:2012:282068

19. Costanzo G, Zoccali C, Maykowski P, Walter CM, Skoch J, Baaj AA. The role of minimally invasive lateral lumbar interbody fusion in sagittal balance correction and spinal deformity. Eur Spine J Off Publ Eur Spine Soc Eur Spinal Deform Soc Eur Sect Cerv Spine Res Soc. 2014;23 Suppl 6:699-704

20. Ambati DV, Wright EK, Lehman RA, Kang DG, Wagner SC, Dmitriev AE. Bilateral pedicle screw fixation provides superior biomechanical stability in transforaminal lumbar interbody fusion: a finite element study. Spine J Off J North Am Spine Soc. 2015;15(8):1812-22

21. Schiffman M, Brau SA, Henderson R, Gimmestad G. Bilateral implantation of low-profile interbody fusion cages: subsidence, lordosis, and fusion analysis. Spine J Off J North Am Spine Soc. 2003:3(5):377-87.

22. Marchi L, Abdala N, Oliveira L, Amaral R, Coutinho E, Pimenta L. Radiographic and clinica evaluation of cage subsidence after stand-alone lateral interbody fusion. J Neurosurg Spine. 2013;19(1):110-8 